\title{
Actions of $\beta$-Amyloid Protein on Human Neurons Are Expressed through the Amylin Receptor
}

\author{
Jack H. Jhamandas, ${ }^{*}$ Zongming Li, ${ }^{*}$ \\ David Westaway, ${ }^{{ }^{\dagger}}$ Jing Yang, ${ }^{{ }^{\dagger}}$ Simran Jassar, ${ }^{*}$ \\ and David MacTavish* \\ From the Division of Neurology,* Department of Medicine, School of \\ Internal Medicine, and the Centre for Prions and Protein Folding \\ Diseases, ${ }^{\dagger}$ University of Alberta, Edmonton, Alberta, Canada
}

Disruption of neurotoxic effects of amyloid $\beta$ protein $(A \beta)$ is one of the major, but as yet elusive, goals in the treatment of Alzheimer's disease (AD). The amylin receptor, activated by a pancreatic polypeptide isolated from diabetic patients, is a putative target for the actions of $\mathrm{A} \beta$ in the brain. Here we show that in primary cultures of human fetal neurons (HFNs), AC253, an amylin receptor antagonist, blocks electrophysiological effects of A $\beta$. Pharmacological blockade of the amylin receptor or its down-regulation using siRNA in HFNs confers neuroprotection against oligomeric $A \beta$-induced caspase-dependent and caspase-independent apoptotic cell death. In transgenic mice (TgCRND8) that overexpress amyloid precursor protein, amylin receptor is up-regulated in specific brain regions that also demonstrate an elevated amyloid burden. The expression of $A \beta$ actions through the amylin receptor in human neurons and temporospatial interrelationship of $A \beta$ and the amylin receptor in an in vivo model of AD together provide a persuasive rationale for this receptor as a novel therapeutic target in the treatment of AD. ( $\mathrm{Am} \mathrm{J}$ Pathol 2011, 178:140-149; DOI: 10.1016/j.ajpath.2010.11.022)

Several lines of evidence support a role for amyloid $\beta$-protein $(A \beta)$ in the pathogenesis of Alzheimer's disease $(A D)$. The genetic data include the occurrence of $A D$ with inherited amyloid precursor protein (APP) mutations adjacent to the $\beta$ - and $\gamma$-secretase cleavage sites, trisomy 21 with the APP gene, and early-onset PS1 and PS2 mutations in the $\gamma$-secretase catalytic subunit. ${ }^{1}$ Other data include neurotoxicity of soluble oligomeric $A \beta$ when applied to neurons ${ }^{2}$ and the generation of APP-overexpressing mice that recapitulate certain neuropathological and behavioral features of $A D{ }^{3}$ Although $A \beta$ exerts a wide range of biological effects and is potently neuro- toxic, there is as yet no unequivocally identified receptor for $A \beta$. Several putative receptor candidates for $A \beta$ have been reported (eg, RAGE receptors, the p $75^{\mathrm{NTR}}$ receptor, scavenger receptors, neuronal nicotinic receptors, and the tachykinin and serpin-enzyme complex receptors), but the functional significance of $A \beta$ interactions with such receptors in the brain has yet to be identified or remains controversial. ${ }^{4-8}$

Several epidemiological studies have attempted to link $\mathrm{AD}$ and diabetes mellitus, a disorder of glucose metabolism and insulin secretion. ${ }^{9,10,11}$ At a cellular level, human amylin (islet amyloid peptide, diabetes-associated peptide), a 37amino-acid amyloidogenic peptide first isolated from protein deposits within the pancreatic islets of Langerhans of non-insulin-dependent diabetes mellitus patients, shares similar biophysical and physiological properties with $A \beta .^{12,13,14,15}$ Electrophysiological data reveal that human amylin and $A \beta$ affect the same suite of potassium conductances in rat cholinergic basal forebrain neurons and that each peptide is able to occlude the response of the other, suggesting a common mechanism of action. ${ }^{16,17}$ Furthermore, $A \beta$ and human amylin not only induce apoptotic cell death in cultured neurons and pancreatic $\beta$-islet cells, but demonstrate a neurotoxicity profile that is identical, including time- and concentration-dependent induction of apoptotic genes. ${ }^{14,15,18}$ Recent data using quantitative iTRAC proteomics analysis (iTRAC stands for "isobaric tag for relative and absolute quantitation") reveal that human amylin and $A \beta$ deregulate identical mitochondrial proteins, further supporting the notion that both amyloidoses have common targets. ${ }^{19}$ Collectively, these observations suggest that the human amylin receptor, which serves as the endogenous receptor for the pancreatic amylin peptide, could also serves as a putative receptor for the expression of the biological effects of $A \beta$.

Supported by the Canadian Institutes of Health Research (MOP 93601) and the Canada Research Chairs program.

Accepted for publication September 23, 2010.

Supplemental material for this article can be found at $h$ ttp://ajp.amjpathol. org or at doi: 10.1016/j.ajpath.2010.11.022

Address reprint requests to Dr. Jack H. Jhamandas, M.D., Ph.D., FRCPC, Department of Medicine (Neurology), 530 Heritage Medical Research Centre, University of Alberta, Edmonton, AB, Canada, T6G 2S2. E-mail: jack.jhamandas@ualberta.ca. 
Dimerization of the calcitonin receptor (CTR) with RAMP3 yields a receptor that binds amylin with a significantly higher affinity than CGRP and adrenomedullin, two other peptides belonging to this family. ${ }^{20,21}$ Several peptides, typically analogs of salmon calcitonin, have been developed as amylin receptor antagonists, chiefly with a view to treating diabetes mellitus. ${ }^{22,23}$ Of these, AC187 and AC253 are highly selective and potent antagonists at the amylin receptor. ${ }^{21,23,24,25}$ We have identified a novel interaction of $A \beta$ and human amylin with the amylin receptor in cholinergic neurons of the rat basal forebrain, where loss of such neurons is linked to the cognitive impairment observed in AD. ${ }^{17}$ We have shown that both the acute electrophysiological and neurotoxic effects of amylin and $A \beta$ in the rat cholinergic basal forebrain neurons can be blocked using amylin receptor antagonists. ${ }^{17,26}$ An important question raised by our observations is whether blockade of the amylin receptor confers neuroprotection against $A \beta$ toxicity in cultures of human neurons. This is a critical issue, because rodents (rats, mice, hamsters), the species in which the effects of $\mathrm{A} \beta$ have been most widely studied, do not develop an age-related human equivalent of $A D$.

In the present study, using whole-cell patch clamp recordings from primary cultures of human fetal neurons (HFNs), we found that acute applications of nanomolar concentrations of $A \beta$ result in an activation of a suite of potassium conductances, which can be blocked by exposure to the amylin receptor antagonist AC253. Furthermore, the amyloid-induced toxicity mediated via caspase-dependent and -independent pathways in HFNs can be attenuated with pretreatment of cultures with AC253 or through down-regulation of the amylin receptor gene expression with small interfering RNA (siRNA). Finally, we demonstrate that in transgenic mice that overexpress APP (TgCRND8), amylin receptor expression in the brain is up-regulated in an age-dependent manner, but only within specific brain regions that demonstrate an increased amyloid burden.

\section{Materials and Methods}

All experiments were conducted in compliance with the relevant laws and the guidelines set by the Canadian Council for Animal Care and with the approval of the Human Research Ethics Board and Animal Care Use Committee (Health Sciences) at the University of Alberta.

\section{Electrophysiological Recordings from HFNs}

HFNs, grown on coverslips, were bathed with oxygenated artificial cerebrospinal fluid that contained (in mmol/L) 140 $\mathrm{NaCl}, 2.5 \mathrm{KCl}, 1.5 \mathrm{CaCl}_{2}, 1.2 \mathrm{MgCl}_{2}, 10$ HEPES, and 33 d-glucose ( $\mathrm{pH}$ 7.4). Whole cell patch-clamp recordings were performed at room temperature $\left(20^{\circ} \mathrm{C}-22^{\circ} \mathrm{C}\right)$ using an Axopatch-200B amplifier in combination with a 1200A interface (Axon Instruments, Foster City, CA). Patch electrodes (thin wall with filament, 1.5-mm diameter; World Precision Instruments, Sarasota, FL) were pulled (PP-83 electrode puller; Narishige Scientific Instrument Lab, Tokyo, Japan) to yield resistances of 3-6 $\mathrm{M} \Omega$. The internal patch pipette solution contained (in mM) $140 \mathrm{~K}$-methylsulfate, 10 EGTA, 5 $\mathrm{MgCl}_{2}, 1 \mathrm{CaCl}_{2}, 10 \mathrm{HEPES}, 2.2 \mathrm{Na}_{2}-\mathrm{ATP}$, and 0.3 Na-GTP $(\mathrm{pH}$ 7.2). All whole-cell recordings were made in currentclamp and voltage-clamp mode, and bridge balance and capacitance compensation were used. After whole-cell configuration was established with voltage-clamp mode (holding potential $=-80 \mathrm{mV}$ ), we waited at least 5 minutes for the cell to stabilize, then started either voltage-clamp studies or switched to current-clamp recording mode. The current and membrane voltages were recorded using a low-pass filter at $5 \mathrm{kHz}$ and were digitized at $10 \mathrm{kHz}$. All data were acquired and analyzed using pClamp8 software v8.0 (Axon Instruments). Whole-cell currents were activated by a voltage-ramp protocol, where the cells were held at $-80 \mathrm{mV}$ and subjected to voltage ramps from -110 to $+30 \mathrm{mV}$ at the rate of $20 \mathrm{mV} / \mathrm{s}$. A 1-second-long hyperpolarizing command to $-110 \mathrm{mV}$ was applied to remove inactivation of $\mathrm{K}^{+}$ channels so that maximum current could be activated during the subsequent slow voltage ramp to $+30 \mathrm{mV}$. $\mathrm{Ca}^{2+}$. dependent $\mathrm{K}^{+}$conductances were isolated using the $\mathrm{BK}$ channel-specific blocker iberiotoxin. Drugs were either bath-applied or delivered via a focal applicator.

\section{Primary Cultures of HFNs}

Neuronal cultures were prepared from 12- to 15-gestational week fetuses with approval of the Human Ethics Research Board at the University of Alberta. The meninges and blood vessels were removed, the brain tissue was washed in minimum essential medium and mechanically dissociated by repeated trituration through a 20gauge needle. Cells were centrifuged at $1500 \mathrm{~g}$ for 10 minutes and resuspended in minimum essential medium with $10 \%$ heat-inactivated fetal bovine serum, $0.2 \%$ N2 supplement, and $1 \%$ antibiotic solution (104 $\mathrm{U}$ of penicillin $\mathrm{G}$ per milliliter, $10 \mathrm{mg}$ streptomycin per milliliter, and $25 \mathrm{mg}$ amphotericin B per milliliter in $0.9 \% \mathrm{NaCl}$ ). ${ }^{27}$ Subsequently, cultures were treated with arabinofuranosylcytosine $(25 \mu \mathrm{mol} / \mathrm{L})$ for 2 weeks and were plated (at a density of $5 \times 10^{-5}$ per well) on 96-well plates. HFN cultures were grown in a $5 \% \mathrm{CO}_{2}$ humidified incubator at $37^{\circ} \mathrm{C}$. Sample wells were immunostained for the neuronal marker microtubule-associated protein 2, and only cultures in which $>70 \%$ of the cells stained positive for the marker were used for experiments. All reagents were obtained from Invitrogen (Burlington, ON, Canada) and antibodies from Sigma-Aldrich (Oakville, ON, Canada).

\section{Treatments and Cell Death Assays}

Soluble oligomeric $A \beta_{1-42}$ or the inverse sequence peptide $A \beta_{42-1}$, human amylin, and AC253 were prepared according to published protocols. ${ }^{28,29}$ All peptides were purchased from American Peptide (Sunnyvale, CA). To determine the dose-dependent toxicity of $A \beta$ peptides and human amylin. HFNs were treated with different concentrations of the peptides $(0.5-50 \mu \mathrm{mol} / \mathrm{L}$ ) (see Supplemental Figure S1 at http://ajp.amipathol.org). In each experiment and in subsequent ones described below, two rows of eight wells each (of a 96-well plate) received the same treatment, 
and each experiment was repeated a minimum of four times. To evaluate the neuroprotective effects of the amylin receptor antagonist AC253 against $A \beta$ toxicity, cultured HFNs were preexposed to AC253 (10 $\mu \mathrm{mol} / \mathrm{L})$ for 24 hours and then to soluble oligomeric $20 \mu \mathrm{mol} / \mathrm{L} A \beta_{1-42}$ or human amylin $(2 \mu \mathrm{mol} / \mathrm{L})$. Cells in adjacent rows of wells received applications of either $20 \mu \mathrm{mol} / \mathrm{L} A \beta_{1-42}, 2 \mu \mathrm{mol} / \mathrm{L}$ human amylin, or $10 \mu \mathrm{mol} / \mathrm{L}$ or AC253. Controls included applications of the inverse sequence $A \beta$ peptide $A \beta_{42-1}$ or no drug. After 48 hours, the control and treated cultures were examined for neuronal survival using a 3-(4,5-Dimethylthiazol-2-yl)-2,5-diphenyltetrazolium bromide (MTT) assay (Sigma-Aldrich). ${ }^{26,30}$

For experiments examining the effects of caspase inhibition on $A \beta$ toxicity, the cell cultures were pretreated for 2 hours with individual caspase inhibitors (20 $\mu \mathrm{mol} / \mathrm{L}$; kit from RD Systems, Minneapolis, MN), followed by exposure to $20 \mu \mathrm{mol} / \mathrm{L} A \beta_{1-42}$ for 48 hours. At the end of this period, the cultures were processed for MTT assay. Each experiment was conducted four times.

\section{Immunoblotting}

Western blotting was performed as described previously.26,30 Briefly, samples of control and treated groups of cultured cells (with $A C 253, A \beta_{1-42}$, or AC253 pretreatment followed by $A \beta_{1-42}$ ) with equal amounts of protein were separated by $12 \%$ polyacrylamide gel electrophoresis and the resolved proteins were transferred onto nitrocellulose membranes and probed with anticaspase 3, 6, and 9 antibodies and also with antibodies to pro- and antiapoptotic intermediaries (cytochrome $c$, SMAC, PUMA, Bax, and Bcl-2; New England Biolabs, Ipswich, MA). Blots were also probed with anti- $\beta$ actin (Abcam, Cambridge, MA) as loading control. To assess whether AC253 also blocked A $\beta$-induced caspase-independent cell death, we performed Western blot and immunohistochemistry to detect cleavage and translocation of apoptosis inducing factor (AIF) from the activated mitochondria using AIF antibody (Santa Cruz Biotechnology, Santa Cruz, CA) and MitoTracker Red dye (Molecular Devices, Sunnyvale, CA). Each experiment was repeated four times. For all quantitative analysis of Western blots, Image J software v1.44j (National Institutes of Health, Bethesda, MD) was used. Relative intensities were calculated by comparing the intensity of protein bands of interest to control $\beta$-actin loading bands.

\section{$\operatorname{siRNA}$}

siRNA corresponding to the human CTR (NM_001742) and RAMP3 (NM_005856) genes, purchased from Open BioSystems (Huntsville, AL), were inserted into a vector (pGIPz) that produced green fluorescent protein. HFNs were plated at a density of 2 million cells $/ \mathrm{ml}$ in a 6 -well plate and cultured for 24 hours before transfection. On the day of transfection, culture media was replaced with OptiMEM (Invitrogen). Four micrograms of plasmid siRNA mixed with Lipofectamine 2000 (Invitrogen) was incubated for 30 minutes and then added to the cultures. Cultures were gently mixed and placed in an incubator at $37^{\circ} \mathrm{C}$ with $5 \% \mathrm{CO}_{2}$ for 10 hours, after which normal cul- ture media was replaced. Subsequently, transfected and non-transfected HFN cultures in 96-well plates were exposed to soluble oligomeric $A \beta_{1-42}(20 \mu \mathrm{mol} / \mathrm{L})$ or the inverse sequence peptide, $A \beta_{42-1}(20 \mu \mathrm{mol} / \mathrm{L})$, and cell survival was measured using the MTT assay.

\section{Enzyme-Linked Immunosorbent Assay for Measurement of $A \beta$ Levels in Brain Regions of TgCRND8 APP and Control Mice}

Brains were quickly removed from 1-, 4-, and 6-month-old TgCRND8 APP mice (human APP695 transgene array incorporating Swedish K670M/N671L and Indiana V717F mutations superimposed on a C57BL6/C3H genetic background) and from control nontransgenic C57BL6/ $\mathrm{C} 3 \mathrm{H}$ littermate mice. The cortex, hippocampus, diagonal band of Broca, brainstem, and cerebellum were dissected and weighed before the preparation of normalized lysates. Proteins from each dissected region were isolated according to the protocol provided with the $\mathrm{A} \beta_{1-42}$ enzyme-linked immunosorbent assay kit (BioSource, Burlington, ON, Canada). In brief, in this protocol a monoclonal antibody specific to the $\mathrm{NH}_{2}$ terminus of the $A \beta_{1-42}$ is coated to the wells of microtiter strips. Proteins are incubated in the well. A secondary antibody specific to the $\mathrm{COOH}$-terminus of the $A \beta_{1-42}$ sequence is then incubated in the wells. Bound rabbit antibody is detected with a horseradish peroxidase-labeled anti-rabbit antibody. Excess anti-rabbit antibody is removed by washing, and then a substrate solution is added and is converted, producing a color. The color is measured at $450 \mathrm{~nm}$ and the intensity of color is directly proportional to the amount of $A \beta_{1-42}$ in the tissue.

\section{Expression of Amylin Receptor in Brain Regions of TgCRND8 APP-Overexpressing Mice}

Under halothane anesthesia, TgCRND8 APP mice (1, 4, and 6 months of age, $n=5$ for each age group) and age-matched control mice ( $n=5$ for each age group) were decapitated and brains were quickly removed. Brains were hemisected and one half of the brain was used for dissecting the cortex, hippocampus, diagonal band of Broca, cerebellum, and brainstem. Tissue was weighed and the placed in cold RIPA (radio-immunoprecipitation assay) buffer with protease inhibitors and proteins were isolated and measured using a Bio-Rad protein assay kit (Mississauga, ON, Canada). Proteins were diluted with SDS sample buffer (New England Biolabs) and were loaded at $30 \mu \mathrm{g}$ per lane on a $12 \%$ agarose gel. Proteins were transferred to nitrocellulose blocked with nonfat milk. Nitrocellulose membranes were incubated with antibodies overnight at $4^{\circ} \mathrm{C}$ on a shaker. Blots were incubated in the following antibodies, one at a time, and were stripped between each application: CTR (1:1000 rabbit; kindly supplied by Professor P. Sexton, Monash University, VIC, Australia), RAMP3 (1:1000 goat; Santa Cruz Biotechnology), 6E10 for $A \beta$ (1:5000 mouse; $6 E 10$; Signet Laboratories, Dedham, MA), and $\beta$-actin (1:1000 mouse; Sigma-Aldrich). Blots were subsequently incu- 
bated with corresponding secondary antibodies labeled with horseradish peroxidase and were washed with Immobilon Western chemiluminescent substrate (Millipore, Billerica, MA). Blots were exposed to X-ray film (Kodak BioMax MR) for 10 seconds to 5 minutes. $X$-ray blots were then scanned and analyzed with Image $J$ software. The other half of the brains from TgCRND8 and control mice was fixed for immunohistochemical analysis of brain sections from cortex and hippocampus to determine $A \beta$ plaque deposition, and the same sections were also double-stained using the CTR antibody.

\section{Statistical Analysis}

Data are presented as means \pm SEM. Unless otherwise indicated, group data were compared using one-way analysis of variance followed by Newman-Keuls post hoc test with the $P$-value set at 0.05 .

\section{Results}

\section{Electrophysiological Effects of A $\beta$ Are Blocked by Amylin Receptor Antagonist}

In HFNs, applications of oligomeric $\mathrm{A} \beta_{1-42}$ caused a timeindependent and concentration-dependent reduction in whole-cell outward currents (WCCs) in the voltage range -30 to $+30 \mathrm{mV}$ (see Supplemental Figure S2 at $h t t p: / /$
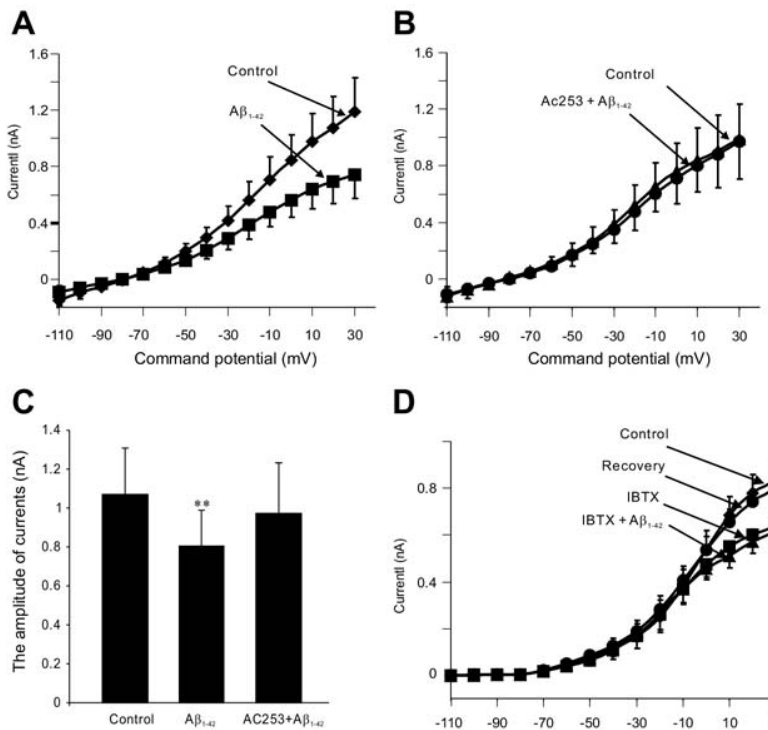

D

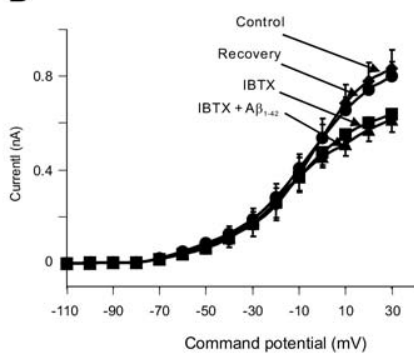

Figure 1. Electrophysiological effects of $\beta$-amyloid $(\mathrm{A} \beta)$ on whole-cell currents in human fetal neurons (HFNs) are expressed via the amylin receptor. A: Bath application of $\mathrm{A} \beta_{1-42}(20 \mathrm{nmol} / \mathrm{L})$ decreases outward currents in the voltage range from -30 to $+30 \mathrm{mV}(n=8)$. B: AC253, a selective amylin receptor antagonist, blocks the effect of $\mathrm{A} \beta_{1-42}$ on whole-cell currents in HFNs $(n=8)$. C: Histograms showing that $\mathrm{A} \beta_{1-42}$-evoked decrease in peak amplitude of the whole-cell currents (measured at $+30 \mathrm{mV}$ ) is decreased in the presence of $\mathrm{AC} 253(n=8, P<0.01)$. D: Under voltage-clamp recording conditions, $\mathrm{Ca}^{2+}$-activated $\mathrm{K}^{+}$currents are blocked in the presence of iberiotoxin (IBTX) $(10 \mathrm{nmol} / \mathrm{L})$, a selective inhibitor of Ic (BK channels) $(n=9$ $P<0.01)$. Subsequent application of $\mathrm{A} \beta_{1-42}(10 \mathrm{nmol} / \mathrm{L})$ in the presence of IBTX did not result in a further significant reduction in such currents. Error bars indicate \pm SEM.
A

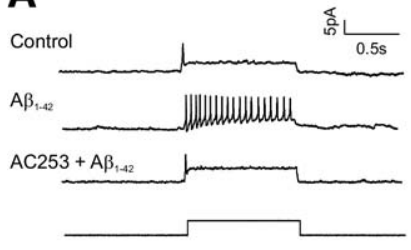

B

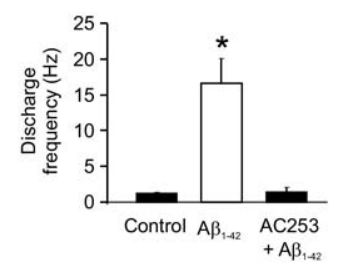

C

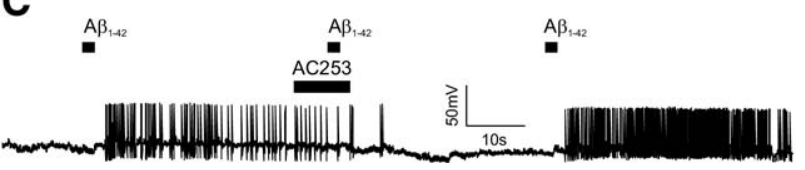

Figure 2. $\mathrm{A} \beta$-evoked increase in excitability of human fetal neurons (HFNs) is blocked by amylin receptor antagonist. A: Under current-clamp conditions, action potential generation evoked by injecting depolarizing current pulses ( $5 \mathrm{pA}, 1$ second) in a HFN is significantly increased in the presence of the evoked $\mathrm{A} \beta_{1-42}(10 \mathrm{nmol} / \mathrm{L})$. Application of AC253 (10 $\mathrm{nmol} / \mathrm{L}$ ), antagonist of amylin receptor, completely blocks the increase in firing frequency induced by $\mathrm{A} \beta_{1-42}$. B: Histograms depict summary of data obtained from five HFNs after application of $\mathrm{A} \beta_{1-42}$ alone and in the presence of $\mathrm{A} \beta_{1-42}$. ${ }^{*}$ Significant difference from control, $P<0.05$. C: Continous current-clamp recording from a HFN depicting membrane depolarization and increased action potential firing with application of $\mathrm{A} \beta_{1-42}(10 \mathrm{nmol} / \mathrm{L})$, which is blocked in the presence of AC253. RMP of cell $=-65 \mathrm{mV}$. Error bars indicate $\pm \mathrm{SEM}$

ajp.amjpathol.org). WCCs were not affected by applications of the inverse sequence $A \beta_{42-1}$ peptide (data not shown). AC253 is a selective peptidergic amylin receptor antagonist that, applied in the concentration range $10^{-5}$ to $10^{-6} \mathrm{~mol} / \mathrm{L}$, has been shown to block the actions of human amylin. ${ }^{17,31}$ We investigated whether the effects of $A \beta$ could also be blocked using this amylin receptor antagonist. Application of $10 \mathrm{nmol} / \mathrm{L}$ AC253 blocked $\mathrm{A} \beta_{1-42}$-induced reduction in WCCs (20 $\mathrm{nmol} / \mathrm{L}, n=8, P<0.01$ ) (Figure $1, \mathrm{~A}$ and $\mathrm{B}$ ). Peak WCC (at $+30 \mathrm{mV}$ ) in the presence of $A \beta_{1-42}$ was significantly reduced, compared with the control level of current $(27.7 \%, n=8, P<0.01)$, but in the presence of AC253, the $A \beta_{1-42}$-evoked response was abolished (Figure 1C). When the high conductance $\mathrm{Ca}^{2+}$-activated $\mathrm{K}^{+}$channels Ic (BK channels) were inhibited with iberiotoxin $(25 \mathrm{nmol} /$ $\mathrm{L}), A \beta_{1-42}$-induced reduction in WCCs was significantly blocked (Figure 1D), indicating that $A \beta$ effects are expressed via this ionic conductance.

Under current-clamp conditions, the number of spikes generated by injection of a current pulse in HFNs was significantly increased in the presence of $A \beta_{1-42}$ (10 $\mathrm{nmol} / \mathrm{L}$ ), compared with control conditions (Figure $2 \mathrm{~A}$ ). Application of AC253 $(10 \mathrm{nmol} / \mathrm{L})$ blocked the increase in excitability induced by $A \beta_{1-42}$. The average number of spikes elicited by current injection was $1.2 \pm 0.3 \mathrm{~Hz}$ under control conditions, which significantly increased to $16.6 \pm 3.5 \mathrm{~Hz}$ in the presence of $\mathrm{A} \beta_{1-42}$ (Figure 2B) $(n=$ $5, P<0.01)$. In the presence of $A C 253$, application of $\mathrm{A} \beta_{1-42}$ did not result in a significant increase in firing $(n=$ $5, P>0.05)$, compared with control. Under resting conditions, application of $\mathrm{A} \beta_{1-42}(10 \mathrm{nmol} / \mathrm{L})$ to HFNs resulted in membrane depolarization and an increase in action potential firing, which were blocked in the presence of AC253 (Figure 2C). 
A
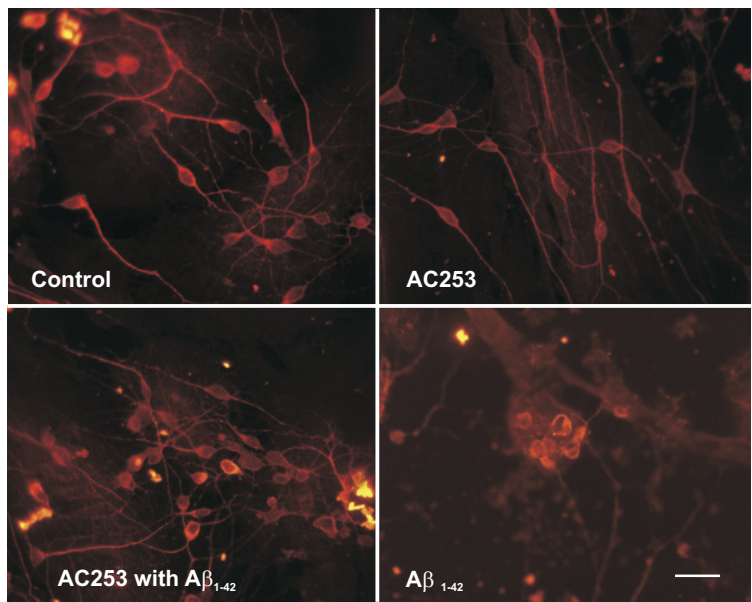

B

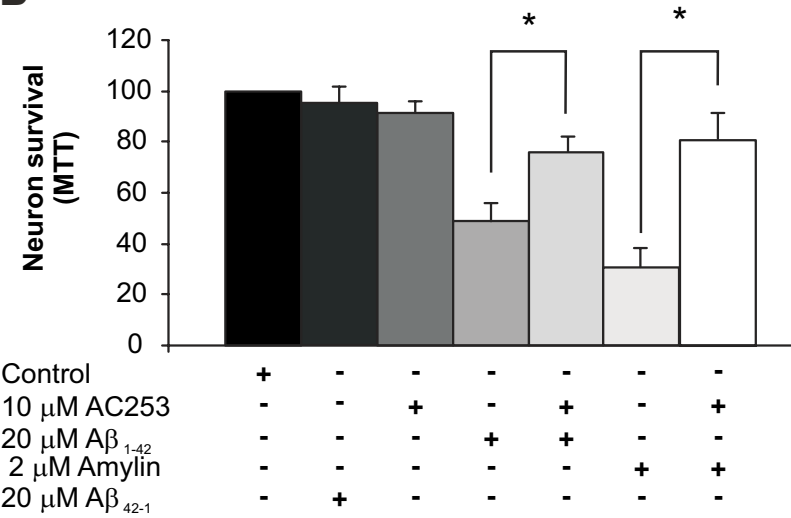

Figure 3. Amylin receptor antagonist protects against $\mathrm{A} \beta$ and human amylin neurotoxicity in primary cultures of human fetal neurons (HFNs). A: $\mathrm{A} \beta_{1-42}$ induces cell death and loss of HFNs (identified with MAP2 staining), compared with control HFN cultures. Loss of HFNs is attenuated with pretreatment of cultures with the amylin receptor antagonist AC253. Applied alone, AC253 has no effect on HFNs. Scale bar $=10 \mu \mathrm{m}$. B: Quantification of the neurotoxic effects of soluble oligomeric $\mathrm{A} \beta_{1-42}$ and human amylin applications to cultures of HFNs. Control HFN cultures treated with the inverse sequence peptide, $A \beta_{42-1}$, do not show evidence of cell death. Neuroprotective effects are apparent in HFN cultures pretreated with AC253 before A $\beta_{1-42}$ or human amylin exposure. Cell survival measured with MTT assay. Pooled data from five experiments. Significant difference $\left({ }^{*} P<0.05\right)$ in neuronal survival with AC253 pretreatment, compared with $\mathrm{A} \beta_{1-42}$ or human amylin applications, respectively. Error bars indicate \pm SEM.

\section{A $\beta$ Neurotoxicity Is Expressed through the Amylin Receptor}

To determine whether $A \beta$ toxicity is expressed via amylin receptors, we used primary cultures of HFNs to initially establish that application of oligomeric $A \beta_{1-42}$ (see Supplemental Figure S3 at http://ajp.amjpathol.org and also the Materials and Methods section) or human amylin evokes concentration-dependent cell death in such neurons (see Supplemental Figure S1 at http://ajp.amjpathol. org). Pretreatment of HFNs for 24 hours with the amylin receptor antagonist AC253 (10 $\mu \mathrm{mol} / \mathrm{L})$ resulted in a significant improvement in neuronal survival of HFNs exposed to either $A \beta_{1-42}(20 \mu \mathrm{mol} / \mathrm{L})$ or human amylin (2 $\mu \mathrm{mol} / \mathrm{L})$ (Figure $3, \mathrm{~A}$ and $\mathrm{B}$ ). Concentrations of extracellularly applied oligomeric $A \beta_{1-42}$ used were based on our data (see Supplemental Figure S1 at http://ajp.amjpathol. org) and data reported in the literature for studies on human neurons. ${ }^{32,33,34}$

To corroborate our pharmacological observations concerning neuroprotective effects of AC253, we also examined whether down-regulation of the amylin receptor using an siRNA approach blunts $A \beta_{1-42}$-induced neurotoxicity in HFNs. To suppress amylin receptor in HFNs, we generated siRNA corresponding to the two components of the amylin receptor, the human CTR (NM_001742) and RAMP3 (NM_005856) genes, and inserted these into a vector ( $\mathrm{pGIPz}$ ) that produces green fluorescent protein (Figure 4A). Controls were packaged with scrambled siRNA. We first confirmed amylin receptor suppression by the siRNAs in HFNs using separately validated antibodies (Figure 4B). HFN cultures were exposed to $A \beta_{1-42}$ at 4 days after transfection and neuronal viability was assessed. Knockdown of the amylin receptor using siRNA rendered $\mathrm{HFNs}$ more resistant to $A \beta_{1-42^{-}}$ induced cell death (Figure 4C).

\section{Amylin Receptor Blockade Attenuates A $\beta$-Induced Caspase-Dependent and -Independent Apoptotic Cell Death}

In animal in vitro models, $A \beta$ may induce apoptosis by activation of a number of cell-death signaling pathways

A
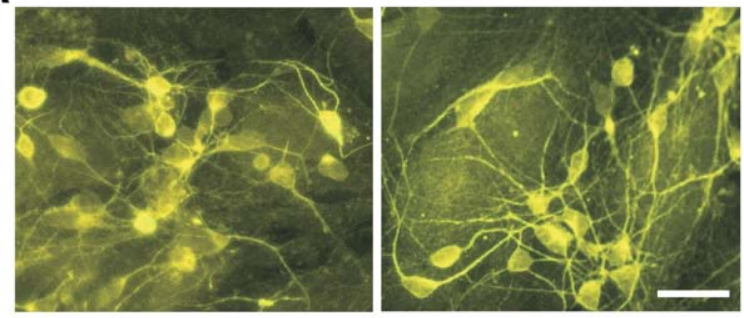

B

C
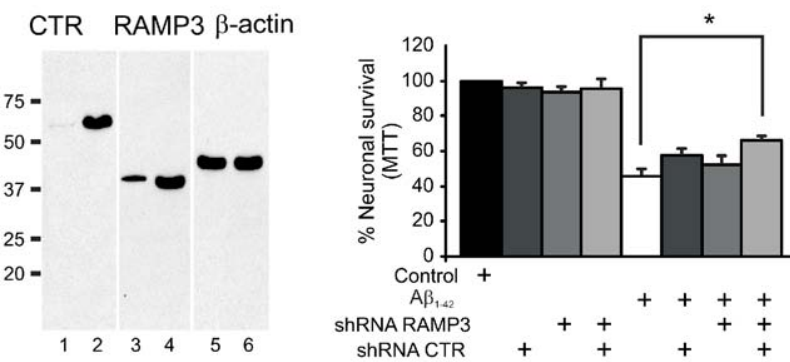

Figure 4. A $\beta$ toxicity is blunted in cultures of human fetal neurons (HFNs) where expression of amylin receptors is down-regulated. A: HFNs transfected with siRNA directed at calcitonin receptor (CTR) and RAMP3, components of the amylin receptor. Fluorescent cells (green fluorescent proteinpositive) identify those cells that express CTR (left) or RAMP3 (right). Scale bar $=10 \mu \mathrm{m}$. B: Western blot of control (nontransfected) and transfected HFNs, showing that CTR and RAMP3 protein are down-regulated with siRNA transfections. Lanes $\mathbf{1}$ and 3: transfected HFN cultures; lanes 2 and 4: control HFN cultures. $\beta$-actin was used as a loading control. C: Neuronal viability after $\mathrm{A} \beta_{1-42}$ exposure in HFNs transfected with vectors for shRNA RAMP3, shRNA CTR, or a combination of the two vectors. A $\beta$ neurotoxicity is attenuated in HFN cultures transfected with shRNA RAMP3 and shRNA CTR. Significant difference compared with nontransfected HFNs exposed to $\mathrm{A} \beta_{1-42},{ }^{*} P$ $<0.05$. Error bars indicate \pm SEM. 


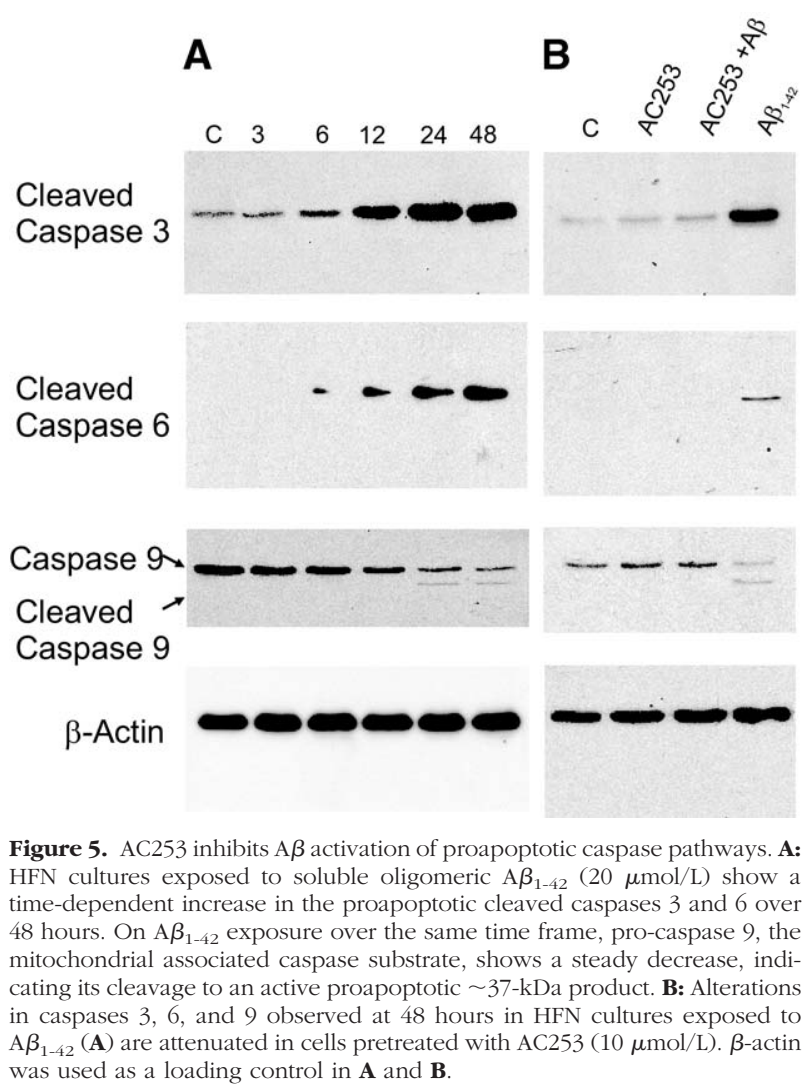

involving caspases, a family of cysteine proteases. ${ }^{35,36}$ Alternatively, A $\beta$-induced cell death may be caspaseindependent, occurring through mitochondrial release, cleavage, and translocation of AIF to the nucleus with consequent DNA fragmentation and nuclear condensation. ${ }^{37}$ We initially identified caspases that are relevant in our HFN model of $A \beta$-induced apoptosis. HFNs pretreated with the pan-caspase inhibitor Z-VAD-FMK or with inhibitors of specific caspases $(3,6,8$, and 9$)$ demonstrated significant resistance to oligomeric $A \beta_{1-42}$ neurotoxicity (see Supplemental Figure S4 at http://ajp. amjpathol.org). Subsequently, we determined whether antagonism of the amylin receptor is able to block the $A \beta$-induced activation of specific caspase pathways. HFN cultures were initially treated with oligomeric $A \beta_{1-42}$ and time-dependent activation of caspases 3,6 , and 9 was detected using antibodies to the cleaved forms of these caspases (Figure 5A). Pretreatment of HFNs with the amylin receptor antagonist AC253 for 24 hours effectively blocked the cleavage of caspases 3,6 , and 9 induced by oligomeric $A \beta_{1-42}$ (Figure 5B). Quantitative analysis of pro-caspase 3 confirmed its reduction (due to conversion to cleaved caspase 3 product) after exposure of HFNs to $A \beta_{1-42}$, but not $A \beta_{42-1}$ (see Supplemental Figure S5A at $h$ ttp://ajp.amjpathol.org). In the presence of AC253, the $A \beta_{1-42}$-induced decrease in the pro-caspase 3 substrate was significantly attenuated, indicating that less of the activated (cleaved) caspase 3 was generated to cause apoptotic cell death.

A similar quantitative analysis revealed that the $A \beta_{1-42^{-}}$ evoked increase in cleaved caspase 9 could be blocked by AC253 pretreatment (see Supplemental Figure S5B at http://ajp.amjpathol.org). Proapoptotic intermediaries in the caspase 9 pathway, including cytochrome $c$, Bax, SMAC, and PUMA, are also increased after exposure to $\mathrm{A} \beta_{1-42}$. Pretreatment with AC253 significantly attenuated or blocked not only the cleavage of caspases 9 but also activation of cytochrome $c$, BAX, SMAC, and PUMA (Figure 6). At the same time, $A \beta_{1-42}$-evoked reduction in antiapoptotic mediators $\mathrm{Bcl}-2$, Akt, and PI3-kinase was attenuated by AC253 (Figure 6).

To determine whether blockade of the amylin receptor also attenuated apoptotic cell death via a caspase-independent pathway, we examined the effects of AC253 pretreatment on $A \beta_{1-42}$-induced cleavage and translocation of AlF from the mitochondria to the nucleus. $A \beta_{1-42}$ (20 $\mu \mathrm{mol} / \mathrm{L})$, but not $A \beta_{42-1}(20 \mu \mathrm{mol} / \mathrm{L})$, caused a timedependent increase in AIF from its $67-\mathrm{kDa}$ form to the cleaved 57-kDa moiety (Figure 7A), which was significantly reduced in HFNs pretreated with AC253 (Figure 7, $B$ and $C$ ). Exposure of HFNs to $A \beta_{1-42}$ under the same

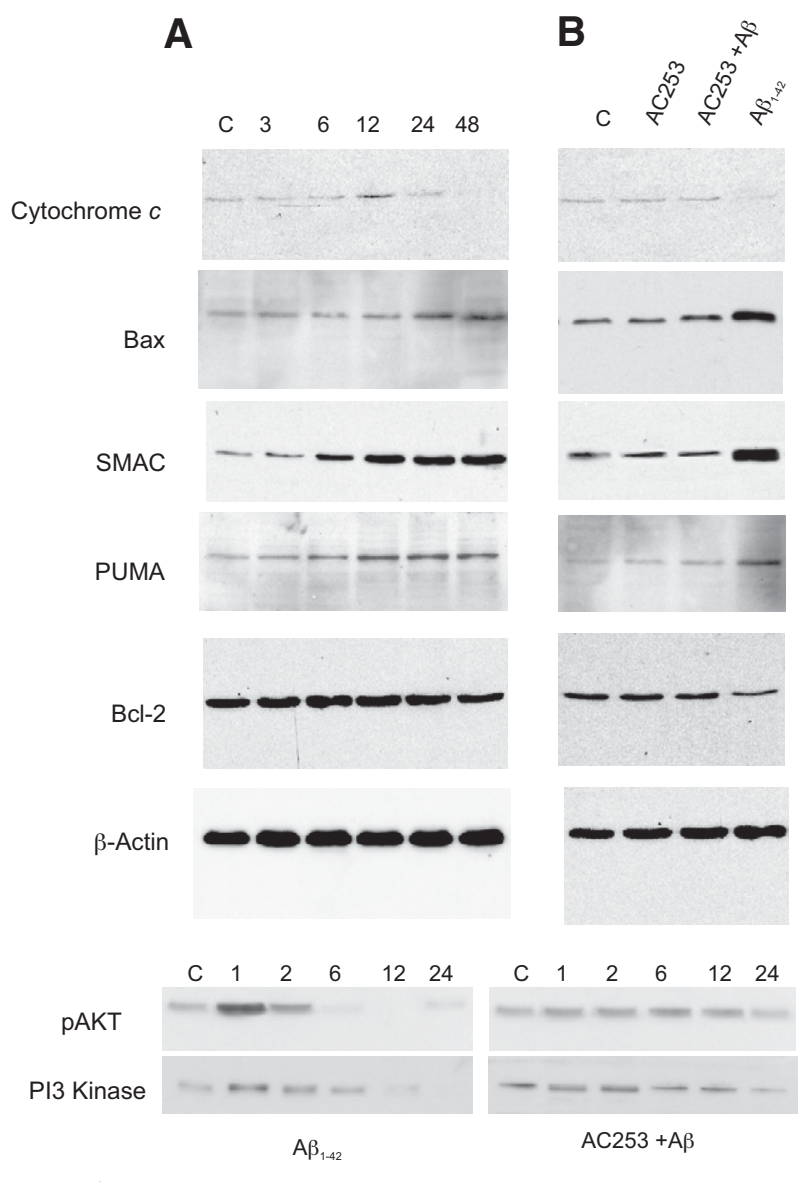

Figure 6. Temporal profile for mediators of apoptosis in cultures of human fetal neurons (HFNs) exposed to $\mathrm{A} \beta$. A: Western blots identifying timedependent alterations in proapoptotic (cytochrome $c$, BAX, SMAC, and PUMA) or antiapoptotic [Bcl-2, phospho-Akt (pAkt), PI-3 kinase] markers in HFN cultures exposed to oligomeric $\mathrm{A} \beta_{1-42}(20 \mu \mathrm{mol} / \mathrm{L})$. Time-course for initial activation and subsequent decrease for pAkt and PI-3 kinase occurs earlier than that for proapoptotic mediators. B: Pretreatment of HFN cultures with amylin receptor antagonist AC253 $(10 \mu \mathrm{mol} / \mathrm{L})$ before $\mathrm{A} \beta_{1-42}$ exposure results in attenuation of proapoptotic markers and at the same time an up-regulation of antiapoptotic proteins shown in $\mathbf{A}$. $\beta$-actin was used as a loading control in $\mathbf{A}$ and $\mathbf{B}$. 

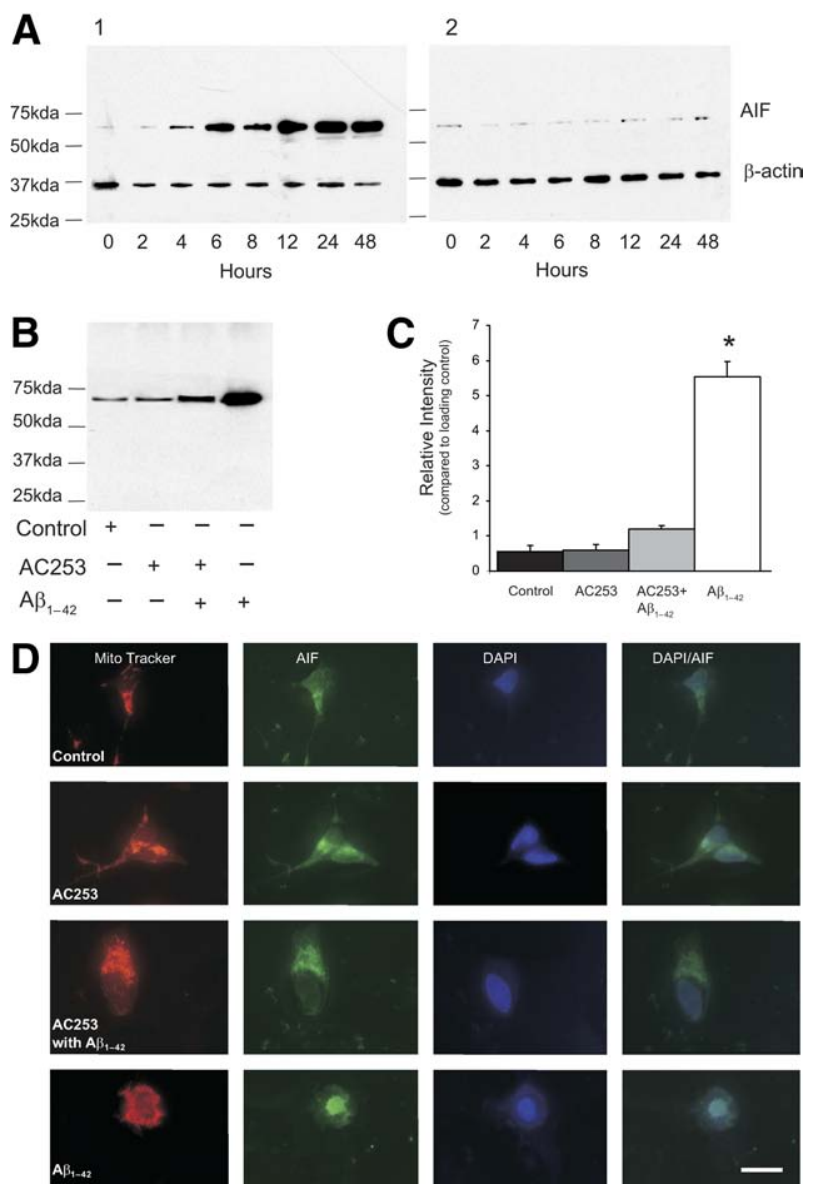

Figure 7. Time course exposure of $\mathrm{A} \beta$ on apoptosis-inducing factor (AIF) expression in cultures of human fetal neurons (HFNs). Western blot (A) shows the time course for AIF expression after exposure to either (1) A $\beta_{1-42}$ (20 $\mu \mathrm{mol} / \mathrm{L})$ or $(2) \mathrm{A} \beta_{42-1}(20 \mu \mathrm{mol} / \mathrm{L})$, the inactive, reverse sequence peptide Lower bands are loading controls, $\beta$-actin. B: AC253 $(10 \mu \mathrm{mol} / \mathrm{L})$ pretreated HFNs exposed to $A \beta_{12}(20 \mu \mathrm{mol} / \mathrm{L})$ show AIF expression is attenuated. $\mathbf{C}$ : Quantification of Western blots for AC253 pretreated HFNs after exposure to $\mathrm{A} \beta_{1-42}(20 \mu \mathrm{mol} / \mathrm{L})$. Relative intensities were calculated by comparing the intensity of AIF bands to $\beta$-actin bands. Significant increase in relative intensity with exposure to $\mathrm{A} \beta_{1-42}$, compared with $\beta$-actin loading control $\left(n=5,{ }^{*} P<0.05\right)$. D: Photomicrographs revealing MitoTracker Red staining (red) to identify mitochondria, immunohistochemistry for AIF (green), and nuclear staining with DAPI (blue) in SK-N-SH neuroblastoma cell line. Overlays in the right column (DAP/AIF) highlight that $\mathrm{A} \beta_{1-42}$-induced translocation of AIF from mitochondria to the nucleus is significantly reduced in AC253 pretreated cells exposed to $\mathrm{A} \beta_{1-42}$ (compare photomicrographs in the overlay column on the right for the last two rows). Scale bar $=20 \mu \mathrm{m}$. Error bars indicate \pm SEM

conditions also resulted in activation of activation of caspase 9 through a caspase-dependent pathway (Figure 5). To confirm cellular localization of AIF within the mitochondria and its translocation to the nucleus, we used immunofluorescence methods in SK-N-SH neuroblastoma cells, which (by virtue of their larger size, relative to HFNs) provide better visualization of the cytoplasm and the spatial relationship of the mitochondria to the nucleus. A $\beta_{1-42}$-treated SK-N-SH cells demonstrated a significant decrease in retention of AIF within the mitochondria (identified using MitoTracker Red dye), but a corresponding increase in AIF within the nuclei (identified using the nuclear stain 4',6-diamidino-2-phenylindole), compared with control cultures (Figure 7D). This nuclear translocation of AIF was not apparent in SK-N-SH cells pretreated with AC253 and subsequently exposed to $\mathrm{A} \beta_{1-42}$. In such cells, AIF was retained within the cytoplasm and colocalized with the mitochondrial-specific marker.

\section{Up-Regulation of Amylin Receptor in Brains of Transgenic Mice That Overexpress A $\beta$}

We sought to determine the relationship between expression of two components of the amylin receptor, RAMP3 and CTR, and the amount of $A \beta$ present in the brains of APP-overexpressing transgenic mice (TgCRND8 APP swe/APP + /-V717F), which serve as a surrogate in vivo model of AD. ${ }^{38}$ Western blot analyses of brains from TgCRND8 mice at 1, 4, and 6 months of age revealed an age-dependent up-regulation of CTR and RAMP3 (Figure 8). Brains of age-matched control mice did not reveal an increase in either amylin receptor components or $A \beta$. The age-dependent increase in $A \beta$ in TgCRND8 mice relative to control age-matched mice was confirmed by enzyme-linked immunosorbent assay including measurement of soluble $A \beta$ species (see Supplemental Figure S6 at http://ajp.amjpathol. org). Furthermore, the increases in CTR and RAMP3 levels in TgCRND8 were specific to brain regions (the cortex, hippocampus, and basal forebrain) that demonstrate a high amyloid burden, compared with other regions (the brainstem and cerebellum) that are relatively spared of amyloid deposition (Figure 8, see also Supplemental Figures S6 and S7 at http://ajp.amjpathol. org). Immunohistochemical localization CTR was observed in close vicinity of $A \beta$ plaque deposition within the cortex, hippocampus, and basal forebrain of TgCRND8 mice (Figure 9).

\section{Discussion}

Our data demonstrate that $A \beta$-induced depression of whole-cell currents in HFNs results in membrane depolarization and a consequent increase in excitability of these neurons. Such effects of $A \beta$ appear to be mediated via an inhibition of the calcium-activated potassium currents (BK channels), because in the presence of iberiotoxin, a specific blocker of these channels, $A \beta$-induced reduction of whole-cell currents was abolished. Importantly, the actions of $A \beta$ under both voltage- and currentclamp conditions could be blocked in the presence of the amylin receptor antagonist AC253. A sustained $A \beta$ evoked neuronal excitation would be expected to affect a number of cellular processes, including augmented calcium entry into the cell and apoptosis through pathways that are activated on elevation of intracellular levels of this ion. Indeed, in the present study a sustained exposure of HFNs to $A \beta$ demonstrated concentration- and time-dependent apoptotic cell death that was attenuated by blockade of the human amylin receptor

$\mathrm{A} \beta$-generated neurotoxicity has been shown to be mediated through both caspase-dependent and caspaseindependent pathways. ${ }^{35,36,39}$ As in other cell culture 
A

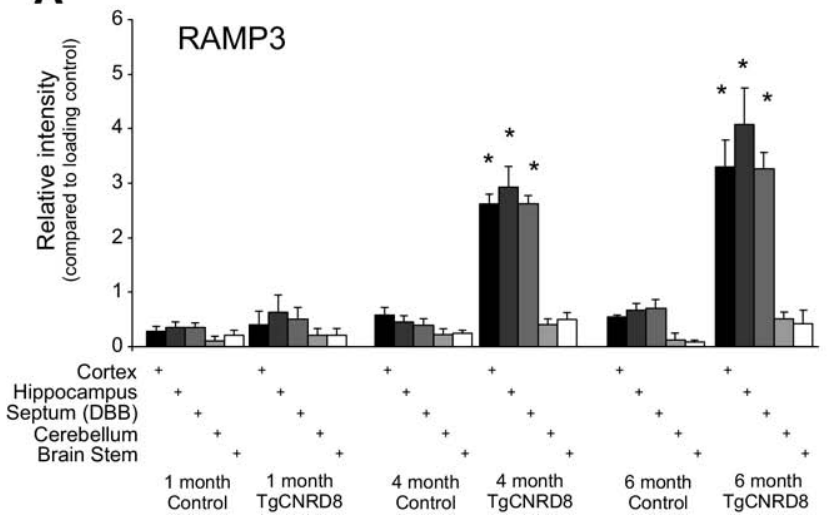

B

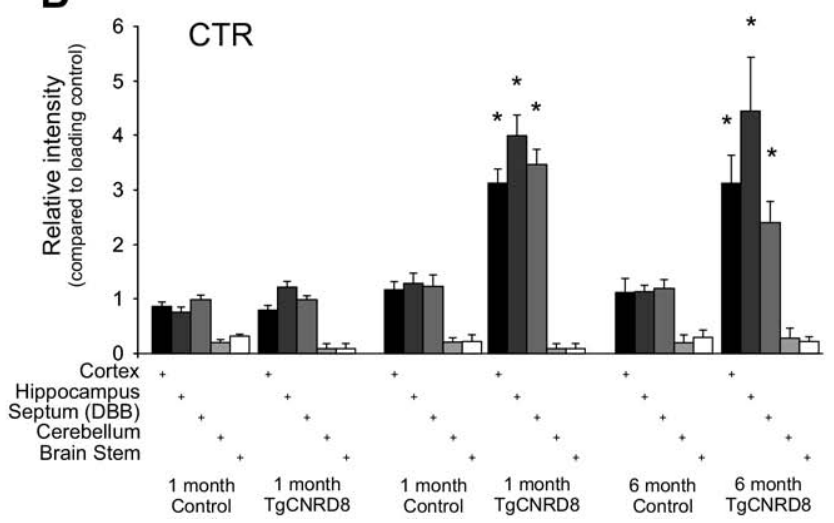

Figure 8. Quantitative analysis of RAMP3 and CTR expression in TgCRND8 mice. Quantification of Western blots for RAMP3, CTR expression in TgCRND8 and control mice at 1, 4, and 6 months of age. Specific brain regions [the cortex, hippocampus, and diagonal band of Broca (DBB)] in 4- and 6-month-old TgCRND8 mice demonstrate an increase in RAMP3 and CTR expression relative to age-matched control mice. Significant difference for transgenic mice compared with age-matched controls within specific brain regions, $n=5$ animals, ${ }^{*} P<0.01$.

systems, exposure of HFNs to $A \beta$ results in activation of caspases $3,6,8$, and 9 . Our data indicate that blockade of the amylin receptor by the antagonist AC253 attenuates cleavage of these caspases associated with apop-

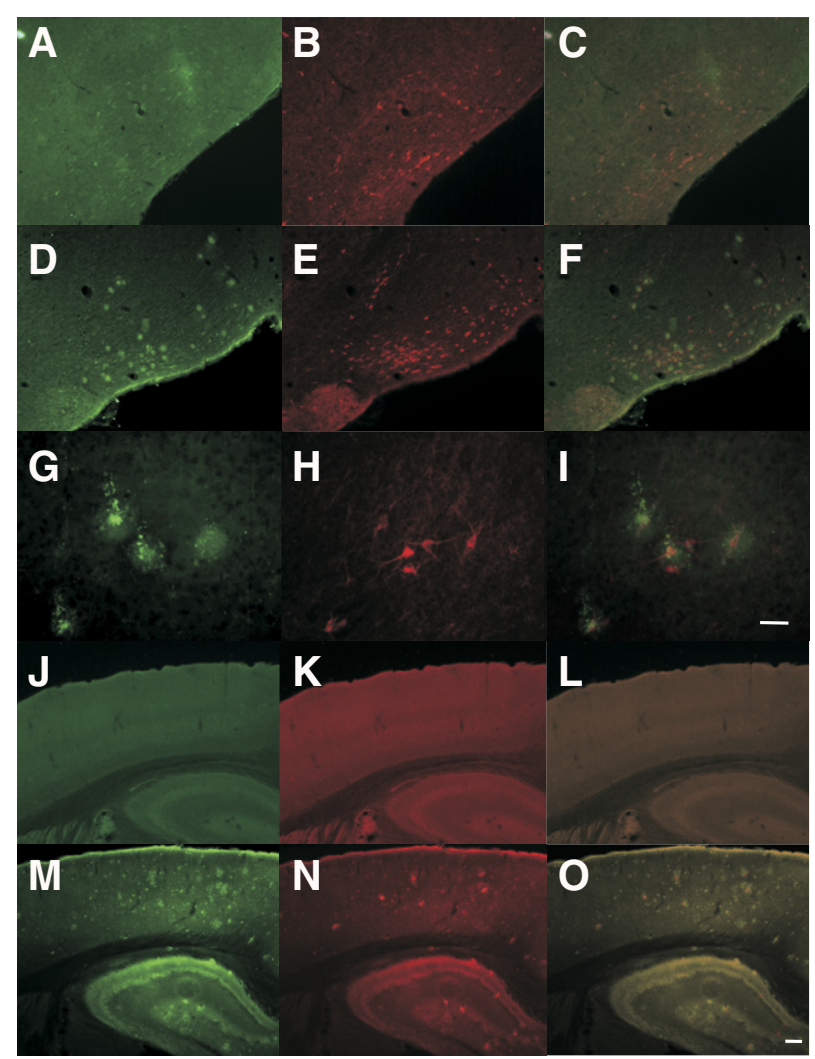

Figure 9. Immunohistochemical localization of $A \beta$ and CTR in brains of TgCRND8 and control mice. Immunohistochemistry for $\mathrm{A} \beta$ (green, $\mathbf{A}, \mathbf{D}, \mathbf{G}$, $\mathbf{J}$, and $\mathbf{M}$ ) and CTR (red, $\mathbf{B}, \mathbf{E}, \mathbf{H}, \mathbf{K}$, and $\mathbf{N}$ ) and overlay of $\mathrm{A} \beta$ and CTR staining $(\mathbf{C}, \mathbf{F}, \mathbf{I}, \mathbf{L}$, and $\mathbf{O})$ in sections from the basal forebrain nucleus, diagonal band of Broca (top two rows), and hippocampus and the overlying cortex (bottom two rows). Photomicrographs $\mathbf{A}, \mathbf{B}, \mathbf{C}, \mathbf{J}, \mathbf{K}$, and $\mathbf{L}$ are from a 6-monthold control mouse. Photomicrographs $\mathbf{D}, \mathbf{E}, \mathbf{F}, \mathbf{M}, \mathbf{N}$, and $\mathbf{O}$ are from a 6-monthold TgCNDR8 mouse. Higher magnification of $\mathrm{A} \beta$ deposits (G), CTR immunostaining $(\mathbf{H})$, and overlay of $\mathrm{A} \beta$ and CTR (I) show the close apposition of amyloid to CTR-labeled profiles. Scale bar $=50 \mu \mathrm{m}$ for $\mathbf{G}, \mathbf{H}, \mathbf{I}$. Scale bar $=100$ $\mu \mathrm{m}$ for remaining panels. totic cell death. On the other hand, $A \beta$ can activate a caspase-independent apoptotic pathway, where cleavage and translocation of mitochondrial AIF to the nucleus result in nuclear condensation and DNA fragmentation. $^{37,40}$ In the present study, we observed a similar activation of a caspase-independent pathway in HFNs treated with $A \beta$. However, HFNs exposed to $A \beta$, but pretreated with AC253, revealed an attenuation of AIF cleavage and retention of AIF within the mitochondrial compartment. $A \beta$-induced down-regulation of antiapoptotic signaling pathways, which occurs in parallel with an up-regulation of proapoptotic mediators, was restored to basal levels after pretreatment of HFNs with AC253. This simultaneous attenuation of multiple proapoptotic pathways (and up-regulation of antiapoptotic mediators) by AC253 suggests that the neuroprotective actions of this compound result from blockade of the neurotoxic interaction of $A \beta$ with human amylin receptors localized on the postsynaptic membrane.

A siRNA approach to down-regulate the expression of amylin receptor components (CTR and RAMP3) rendered transfected HFN cultures resistant to $A \beta$ toxicity. Neuroprotection against $A \beta$ toxicity with the siRNA ap-

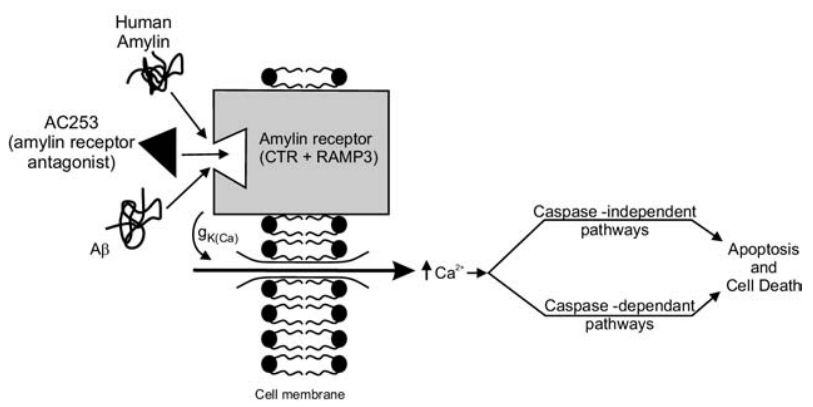

Figure 10. Schematic summarizing $A \beta$-amylin receptor interactions. $A \beta$ activation of amylin receptor (CTR and RAMP3 complex) results in depression of calcium-activated potassium conductance $\left(g_{\mathrm{K}} \mathrm{Ca}\right)$, membrane depolarization, and consequent entry of calcium into the cell. This triggers an activation of caspase-dependent and -independent signaling pathways that converge to cause apoptotic cell death. Blockade of the amylin receptor with the antagonist AC253 results in an inhibition of $\mathrm{A} \beta$-mediated membrane events and apoptotic cell death. 
proach was not as robust as with the use of the amylin receptor antagonist AC253. This observation is not surprising, however, considering that Lipofectamine-facilitated transfection rates of primary neuronal cell cultures under optimum conditions are at best in 30\%-40\% range, a level achieved in our experiments. Therefore, neuroprotection conferred by down-regulation of the amylin receptor in primary cultures of HFNs would be expected to be less effective against $A \beta$ toxicity than is pharmacological blockade of the amylin receptor. Nonetheless, results from siRNA experiments complement our pharmacological data concerning ability of the amylin receptor antagonist AC253 to block both the electrophysiological and neurotoxic effects of $A \beta$. The precise nature of how AC253 blocks A $\beta$ effects is unclear, as is the case for other receptors that have been postulated as targets for the actions of $A \beta$. However, the ability to blunt $A \beta$ toxicity by down-regulating amylin receptors located on HFNs and electrophysiological data showing that direct $A \beta$-evoked responses could be blocked by the amylin receptor antagonist AC253 appear to suggest some form of a direct interaction between $A \beta$ and the postsynaptically located amylin receptors on HFNs. Collectively, these studies point to a central role for the amylin receptor as a target for the characteristic lethal actions of $A \beta$ on human neurons.

An important issue raised by the electrophysiological and cell culture experiments concerns the relationship of the amylin receptor to the overexpression of $A \beta$ that is observed under in vivo conditions, such as in the brains of transgenic mouse models of AD. TgCRND8 APP mice carrying combined APP Swedish (K670M/N671L) and Indiana (V717F) mutations exhibit an aggressive pathology that by 6 months consists of large numbers of core plaques and peculiar floccular diffuse parenchymal deposits. ${ }^{38,41}$ The present study shows that there is a timedependent increase in the two amylin receptor components (CTR and RAMP3) relative to age-matched controls that parallels the overexpression of $A \beta$ observed in TgCRND8 APP mice. These findings suggest that the increased levels of $A \beta$ (both in soluble and plaque form) observed in these mice cause deleterious effects through an overexpression of the putative target, the amylin receptor. Thus, an interaction between $A \beta$ and amylin receptors over an extended period of time could result in synaptic disruption, neuronal loss, and the behavioral deficits that are a hallmark of AD.

For such a hypothesis to be tenable, the up-regulation of the amylin receptor would be have to demonstrate a regional specificity within the brain, such that the receptor is preferentially increased only in specific areas demonstrating a large burden of amyloid (ie, the cortex, hippocampus, and basal forebrain, but not the brainstem or cerebellum). Indeed, our observations support this notion, because the levels of amylin receptor markers (CTR and RAMP3) were significantly increased only in the aforementioned areas and, in addition, these correlated with the high levels of $A \beta$ detected in the very same regions. These observations also suggest that the mechanism that elevates amyloid burden in transgenic mice may also signal up-regulation of the amylin receptor.
Numerous epidemiological studies have linked type 2 diabetes mellitus with an increased risk of developing AD. ${ }^{11,42}$ At a cellular level, the pathophysiological linkage between the two conditions has been based on several avenues of investigation that point to a potential role for insulin signaling and insulin-degrading enzyme in neurodegeneration and cognitive decline. ${ }^{43,44}$ Accelerated rate of formation and accumulation of advanced glycation end products are observed in both type 2 diabetes mellitus and AD. ${ }^{45,46}$ Furthermore, RAGE, the receptor for advanced glycation end products, has been shown to promote intraneuronal accumulation of $A \beta$ (and the consequent toxicity attributed to this peptide) and is also implicated in the development of diabetic vascular complications. ${ }^{47}$ Although the involvement of amylin and its receptor in the development of diabetes has been known for some time, ${ }^{12}$ the present study provides novel evidence linking the amylin receptor to neurodegenerative mechanisms in human neurons and in a transgenic APP. overexpressing mouse model of $A D$.

Because $A \beta$ evokes cell death through a number of apoptotic pathways (both caspase-dependent and caspaseindependent), neuroprotective strategies aimed at attenuating the apoptotic actions of $A \beta$ are more likely to be effective if directed upstream to activation of these multiple intracellular signaling pathways. A working model summarizing the observations from the present study is presented in Figure 10. Based on this model, AC253 and similar amylin-receptor-based compounds that block the expression of $A \beta$ effects via human amylin may have considerable potential as a treatment approach for AD.

\section{Acknowledgment}

We thank Dr. Khem Jhamandas for useful comments and suggestions on the manuscript.

\section{References}

1. Brouwers N, Sleegers K, Van Broeckhoven C: Molecular genetics of Alzheimer's disease: an update. Ann Med 2008, 40:562-583

2. Yankner BA, Lu T: Amyloid beta-protein toxicity and the pathogenesis of Alzheimer disease. J Biol Chem 2009, 284:4755-4759

3. Price DL, Wong PC, Markowska AL, Lee MK, Thinakaren G, Cleveland DW, Sisodia SS, Borchelt DR: The value of transgenic models for the study of neurodegenerative diseases. Ann N Y Acad Sci 2000 920:179-191

4. Chen X, Walker DG, Schmidt AM, Arancio O, Lue LF, Yan SD: RAGE: a potential target for Abeta-mediated cellular perturbation in Alzheimer's disease. Curr Mol Med 2007, 7:735-742

5. Salminen A, Ojala J, Kauppinen A, Kaarniranta K, Suuronen T: Inflammation in Alzheimer's disease: amyloid-beta oligomers trigger innate immunity defence via pattern recognition receptors. Prog Neurobiol 2009, 87:181-194

6. Sotthibundhu A, Sykes AM, Fox B, Underwood CK, Thangnipon W, Coulson EJ: Beta-amyloid(1-42) induces neuronal death through the p75 neurotrophin receptor. J Neurosci 2008, 28:3941-3946

7. Parri RH, Dineley TK: Nicotinic acetylcholine receptor interaction with beta-amyloid: molecular, cellular, and physiological consequences. Curr Alzheimer Res 2010, 7:27-39

8. Mehta TK, Dougherty JJ, Wu J, Choi CH, Khan GM, Nichols RA: Defining pre-synaptic nicotinic receptors regulated by beta amyloid in mouse cortex and hippocampus with receptor null mutants. J Neurochem 2009, 109:1452-1458 
9. Sun MK, Alkon DL: Links between Alzheimer's disease and diabetes. Drugs Today (Barc) 2006, 42:481-489

10. Craft S: Insulin resistance and Alzheimer's disease pathogenesis potential mechanisms and implications for treatment. Curr Alzheimer Res 2007, 4:147-152

11. Lin L, Hölscher C: Common pathological processes in Alzheimer disease and type 2 diabetes: a review. Brain Res Rev 2007, 56:384402

12. Cooper GJ, Willis AC, Clark A, Turner RC, Sim RB, Reid KB: Purification and characterization of a peptide from amyloid-rich pancreases of type 2 diabetic patients. Proc Natl Acad Sci USA 1987, 84:8628-8632

13. Arispe N, Pollard HB, Rojas E: Giant multilevel cation channels formed by Alzheimer disease amyloid beta-protein [A beta P-(1-40)] in bilayer membrane. Proc Natl Acad Sci USA 1993, 90:10573-10577

14. May PC, Boggs LN, Fuson KS: Neurotoxicity of human amylin in rat primary hippocampal cultures: similarity to Alzheimer's disease amyloid-beta neurotoxicity. J Neurochem 1993, 61:2330-2333

15. Tucker HM, Rydel RE, Wright S, Estus S: Human amylin induces "apoptotic" pattern of gene expression concomitant with cortical neuronal atrophy. J Neurochem 1998, 71:506-516

16. Jhamandas JH, Cho C, Jassar B, Harris K, MacTavish D, Easaw J: Cellular mechanisms for amyloid-beta protein activation of rat cholinergic basal forebrain neurons. J Neurophysiol 2001, 86:1312-1320

17. Jhamandas JH, Harris KH, Cho C, Fu W, MacTavish D: Human amylin actions on rat cholinergic basal forebrain neurons: antagonism of beta-amyloid effects. J Neurophysiol 2003, 90:3130-3136

18. Lim YA, Ittner LM, Lim YL, Götz J: Human but not rat amylin shares neurotoxic properties with Abeta42 in long-term hippocampal and cortical cultures. FEBS Lett 2008, 582:2188-2194

19. Lim YA, Rhein V, Baysang G, Meier F, Poljak A, Raftery MJ, Guilhaus M, Ittner LM, Eckert A, Götz J: Abeta and human amylin share a common toxicity pathway via mitochondrial dysfunction. Proteomics 2010, 10:1621-1633

20. Poyner DR, Sexton PM, Marshall I, Smith DM, Quirion R, Born W, Muff $R$, Fischer JA, Foord SM: International Union of Pharmacology. XXXII. The mammalian calcitonin gene-related peptides, adrenomedullin, amylin, and calcitonin receptors. Pharmacol Rev 2002, 54:233-246

21. Young A: Receptor pharmacology. Adv Pharmacol 2005, 52:47-65

22. Hay DL, Christopoulos G, Christopoulos A, Sexton PM: Amylin receptors: molecular composition and pharmacology. Biochem Soc Trans 2004, 32:865-867

23. Hay DL, Christopoulos G, Christopoulos A, Poyner DR, Sexton PM: Pharmacological discrimination of calcitonin receptor: receptor activity-modifying protein complexes. Mol Pharmacol 2005, 67:1655-1665

24. Cantarella G, Martinez G, Di Benedetto G, Loreto C, Musumeci G, Prato A, Lempereur L, Matera M, Amico-Roxas M, Bernardini R, Clementi G: Protective effects of amylin on reserpine-induced gastric damage in the rat. Pharmacol Res 2007, 56:27-34

25. Morfis M, Tilakaratne N, Furness SG, Christopoulos G, Werry TD, Christopoulos A, Sexton PM: Receptor activity-modifying proteins differentially modulate the $G$ protein-coupling efficiency of amylin receptors. Endocrinology 2008, 149: 5423-5431

26. Jhamandas JH, MacTavish D: Antagonist of the amylin receptor blocks beta-amyloid toxicity in rat cholinergic basal forebrain neurons. J Neurosci 2004, 24:5579-5584

27. Power C, McArthur JC, Nath A, Wehrly K, Mayne M, Nishio J, Langelier T, Johnson RT, Chesebro B: Neuronal death induced by brainderived human immunodeficiency virus type 1 envelope genes differs between demented and nondemented AIDS patients. J Virol 1998, 72:9045-9053

28. Stine WB Jr, Dahlgren KN, Krafft GA, LaDu MJ: In vitro characterization of conditions for amyloid-beta peptide oligomerization and fibrillogenesis. J Biol Chem 2003, 278:11612-11622

29. White JA, Manelli AM, Holmberg KH, Van Eldik LJ, Ladu MJ: Differential effects of oligomeric and fibrillar amyloid-beta 1-42 on astrocyte-mediated inflammation. Neurobiol Dis 2005, 18:459-465
30. Ding X, MacTavish D, Kar S, Jhamandas JH: Galanin attenuates betaamyloid (Abeta) toxicity in rat cholinergic basal forebrain neurons. Neurobiol Dis 2006, 21:413-420

31. Riediger T, Rauch M, Schmid HA: Actions of amylin on subfornical organ neurons and on drinking behaviour in rats. Am J Physiol 1999, 276:R514-521

32. Mattson MP, Cheng B, Davis D, Bryant K, Lieberburg I, Rydel RE: beta-Amyloid peptides destabilize calcium homeostasis and render human cortical neurons vulnerable to excitotoxicity. J Neurosci 1992 12:376-389

33. Afkhami-Goli A, Noorbakhsh F, Keller AJ, Vergnolle N, Westaway D, Jhamandas JH, Andrade-Gordon P, Hollenberg MD, Arab H, Dyck $\mathrm{RH}$, Power C: Proteinase-activated receptor-2 exerts protective and pathogenic cell type-specific effects in Alzheimer's disease. J Immunol 2007, 179:5493-5503

34. Ryan SD, Whitehead SN, Swayne LA, Moffat TC, Hou W, Ethier M, Bourgeois AJ, Rashidian J, Blanchard AP, Fraser PE, Park DS, Figeys D, Bennett SA: Amyloid-beta42 signals tau hyperphosphorylation and compromises neuronal viability by disrupting alkylacylglycerophosphocholine metabolism. Proc Natl Acad Sci USA 2009, 106:20936-20941

35. Villa P, Kaufmann SH, Earnshaw WC: Caspases and caspase inhibitors. Trends Biochem Sci 1997, 22:388-393

36. Yuan J, Yankner BA: Apoptosis in the nervous system. Nature 2000 , 407:802-809

37. Cregan SP, Dawson VL, Slack RS: Role of AIF in caspase-dependent and caspase-independent cell death. Oncogene 2004, 23: 2785-2796

38. Chishti MA, Yang DS, Janus C, Phinney AL, Horne P, Pearson J, Strome R, Zuker N, Loukides J, French J, Turner S, Lozza G, Grilli M, Kunicki S, Morissette C, Paquette J, Gervais F, Bergeron C, Fraser PE, Carlson GA, George-Hyslop PS, Westaway D: Early-onset amyloid deposition and cognitive deficits in transgenic mice expressing a double mutant form of amyloid precursor protein. J Biol Chem 2001 276:21562-21570

39. Bredesen DE, Rao RV, Mehlen P: Cell death in the nervous system. Nature 2006, 443:796-802

40. Krantic S, Mechawar N, Reix S, Quirion R: Apoptosis-inducing factor: a matter of neuron life and death. Prog Neurobiol 2007, 81:179-196

41. Van Vickle GD, Esh CL, Kalback WM, Patton RL, Luehrs DC, Kokjohn TA, Fifield FG, Fraser PE, Westaway D, McLaurin J, Lopez J, Brune D, Newel AJ, Poston M, Beach TG, Roher AE: TgCRND8 amyloid precursor protein transgenic mice exhibit an altered gammasecretase processing and an aggressive, additive amyloid pathology subject to immunotherapeutic modulation. Biochemistry 2007 46:10317-10327

42. Götz J, Ittner LM, Lim YA: Common features between diabetes mellitus and Alzheimer's disease. Cell Mol Life Sci 2009, 66:1321-1325

43. Farris W, Mansourian S, Chang Y, Lindsley L, Eckman EA, Frosch MP, Eckman CB, Tanzi RE, Selkoe DJ, Guenette S: Insulin-degrading enzyme regulates the levels of insulin, amyloid beta-protein, and the beta-amyloid precursor protein intracellular domain in vivo. Proc Natl Acad Sci USA 2003, 100:4162-4167

44. Gasparini L, Xu H: Potential roles of insulin and IGF-1 in Alzheimer's disease. Trends Neurosci 2003, 26:404-406

45. Münch G, Schinzel R, Loske C, Wong A, Durany N, Li JJ, Vlassara H, Smith MA, Perry G, Riederer P: Alzheimer's disease-synergistic effects of glucose deficit, oxidative stress and advanced glycation endproducts. J Neural Transm 1998, 105:439-461

46. Yamagishi S, Takeuchi M, Inagaki Y, Nakamura K, Imaizumi T: Role of advanced glycation end products (AGEs) and their receptor (RAGE) in the pathogenesis of diabetic microangiopathy. Int J Clin Pharmacol Res 2003, 23:129-134

47. Ledesma MD, Bonay P, Colaço C, Avila J: Analysis of microtubuleassociated protein tau glycation in paired helical filaments. $J$ Bio Chem 1994, 269:21614-21619 